\title{
LANGUAGE ECOLOGY AND ENGLISH AS A LINGUA FRANCA IN A GLOCAL MULTICULTURAL SOCIETY: OPENING INTERCULTURAL WINDOWS
}

\author{
LA ECOLOGÍA LINGÜÍSTICA Y EL INGLÉS COMO LINGUA \\ FRANCA EN UNA SOCIEDAD MULTICULTURAL GLOCAL: \\ ABRIENDO VENTANAS INTERCULTURALES
}

Salvatore Le Donne

s.ledonne@ virgilio.it

Fecha de recepción: 15/06/2017

Fecha de aceptación: 12/12/2017

\begin{abstract}
This study is a conceptual and descriptive review of the working field of language ecology from a postmodernist perspective. It looks into the pluricentric, holistic, intercultural and multidisciplinary implications of language ecology and English as a lingua franca in a variety of EU glocal, i.e. global and local, sociolinguistic scenarios. Positing a semiotic construct of language as an open and inclusive process and a close interrelationship between language and power dynamics (Bourdieu, 1982,1986,1991), the analysis gives an overview of theoretical questions related to the import of language ecology, diversity, bi/multiligualism and the functional role of English as a lingua franca and lingua mundi in the EU, in a geocentric, contextual, action-oriented and critical approach to language as opposed to the anthropocentric, decontextualized and fractional constructs of 20th century rational structuralism. Grounded in hands-on English-teaching experience, it aims to spotlight the weaknesses of a monolingual and monocultural mindset and focuses on the dilemma between a de facto English dominance and glocal bilingual and multilingual concerns across the European Union. Capitalizing on Foucalt's inspiring paradigm of «problematization» $(1972,1977,1980,1985)$, the article is meant to stimulate critical thought and discussion of ELF application to educational and occupational settings
\end{abstract}


for the purpose of a situated, even-handed and encompassing language ecology opening «[...] windows through which we are better able to see reality» (Natsoulas, 1993).

KEY WORDS: Language ecology; language education; language diversity; lingua franca; lingua mundi, glocal.

\section{RESUMEN}

Este estudio es una revisión conceptual y descriptiva del campo de la ecología lingüística desde un punto de vista posmoderno. En él se examinan las implicaciones pluricéntricas, holísticas, interculturales y multidisciplinares de la ecología lingüística y del inglés como lingua franca en una variedad de escenarios sociolingüísticos glocales de la UE, es decir, globales y locales. Partiendo de una construcción semiótica del lenguaje como un proceso abierto e inclusivo y una interconexión estricta entre las dinámicas del lenguaje y el poder (Bourdieu, 1982, 1986, 1991), el análisis ofrece una visión general de cuestiones teóricas relacionadas con la importancia de la ecología lingüística, la diversidad, el bi / multiligualismo y el papel funcional del inglés como lingua franca y lingua mundi en la UE, en un enfoque geocéntrico, contextual, orientado a la acción y crítico del lenguaje en oposición a los constructos antropocéntricos, descontextualizados y fraccionarios del estructuralismo racional del siglo xx. Basado en la práctica de la enseñanza del inglés, el trabajo destaca las debilidades de una visión monolingüe y monocultural y se centra en el dilema entre un dominio de facto del inglés y las preocupaciones glocales bilingües y multilingües en toda la Unión Europea. Aprovechando el paradigma inspirador de «problematización» de Foucalt (1972, 1977, 1980, 1985), el artículo pretende estimular la reflexión crítica y el debate sobre la aplicación del inglés como lingua franca a marcos educativos y ocupacionales con el objetivo de una ecología lingüística situada, equitativa e inclusiva que abra «[...] ventanas por las cuales podamos ver mejor a la realidad» (Natsoulas, 1993).

Palabras clave: Ecología lingüística, educación lingüística, diversidad lingüística, lingua franca; lingua mundi, glocal.

\section{INTRODUCTION. A GEOCENTRIC AND HOLISTIC CONCEPTION OF LANGUAGE}

From the German biologist Ernst Haeckel (1866) onwards, ecology has encompassed a variety of ideological and operative concerns and perspectives. The late 20th century emphasis on real-world utterance and performance by pragmatists and on text and discourse by discourse analysts had laid the ground for a holistic, world-friendly, situated, interrelated and expansive centrality of the context in the language ecology representation of language, both in the theoretical assumptions and the pedagogical applications to language learning and teaching. Over the last decades, applied linguistic research has tried to condense that burgeoning variety into a working theory of language ecology inspired by the much- 
debated socio-economic phenomenon of globalization and operatively applied to diverse sociocultural sceneries.

In 1972 Einar Haugen introduced the metaphor in his seminal paper titled The Ecology of Language based on «The Stigmata of Bilingualism», a lecture given at Brown University, Providence, Rhode Island, USA, in 1970. According to Haugen, language ecology may be defined as «[...] the study of interactions between any given language and its environment [...]» (Creese, Martin \& Hornberger, 2008: i) The term is a metaphor derived from the study of living beings. It implies the view that one can study languages as one studies the interactions of organisms with and within their environments and contains a number of subsidiary metaphors and assumptions. Accordingly, languages can be regarded as entities located in time and place and the ecology of languages is in part different from that of their speakers:

[...] it seems to me that the term 'ecology of language' covers a broad range of interests within which linguists can cooperate significantly with all kinds of social scientists towards an understanding of the interaction of languages and their users. One may even venture to suggest that ecology is not just a name of a descriptive science, but in its application has become the banner of a movement for environmental sanitation. The term could include also in its application to language some interest in the general concern among laymen over the cultivation and preservation of language. Ecology suggests a dynamic rather than a static science, something beyond the descriptive that one might call predictive and even therapeutic. What will be, or should be, for example, the role of 'small' languages; and how can they, or any other language be made 'better', 'richer', and more 'fruitful' for mankind? (Haugen, 1972, reprinted in Fill \& Mühlhäusler, 2001: 60)

Haugen (1972) ushered in a form of linguistics which used the metaphor of an ecosystem to describe the relationships among the diverse forms of language found in the world and the groups of people who speak them. The notion of the environment includes both the society that uses the language and the human mind in which it may be surrounded by other languages, and implies the question: what concurrent languages are employed by speakers of a given language? (336) Haugen (325) referred to two distinct levels, or fields of enquiry, of language ecology:

- A psychological level: «[...] its interaction with other languages in the minds of biand multilingual speakers» (ibid.) and

— A sociological level: «[...] its interaction with the society in which it functions as a medium of communication» (ibid.).

Yet, in the end, who matters is people: «[...] the people who learn it, use it, and transmit it to others» (ibid.).

When Haugen (1972) first used «ecology» as a metaphor in linguistics, he formulated ten questions which all have to do with the position of a language in relation to other languages, its different varieties, its status in a society, its overlap with other languages and the degree of bilingualism of its users. However, he was already aware of the more 
«ideological» meaning of ecology when he suggested «[...] that ecology is not just the name of a descriptive science, but in its application has become the banner of a movement for environmental sanitation» (Fill \& Mühlhäusler, 2001: 59). Haugen also addressed the role of small languages and thus anticipated some of the topics which later became the central area of ecolinguistic research (Block de Behar et al. 2009: 187). In other terms, the American linguist soon came to view linguistics as dynamic, committed, real-world intervention instead of intellectual and, often, decontextualized description. Languages have frequently been compared to organisms which grow, have a life of their own and may die from a number of causes, among them suppression by governments, but also natural extinction through the death of the last speakers. What is new about Haugen's ecological metaphor (1972) is that it compares languages not to individual living beings but rather to whole species, and that it shows languages as existing not in isolation but in their «environment», as part of an ecological system with all its interrelations and its forms of equilibrium, which may be stable or in danger of getting destabilized. The environment of a language is, as mentioned, of a twofold nature:

1. On the one hand, it is the languages interacting in the speaker's mind.

2. On the other, it is the other languages spoken in a society and the culture of this society. Creese, Martin and Hornberger (2008: i) write that «The true environment of a language is the society that uses it as one of its codes».

Language contacts can thus be divided into individual and societal ones. Van Lier's (2004) ecocentric worldview ushers in a new encompassing conception of language and leads him to pose a fundamental question, «[...] What is language?» [...], asking the reader for a satisfactory answer beyond the componential notion of building blocks - «[...] it consists-of sounds, words, sentences, and so on $[\ldots] \gg-$ or «[...] a more general functional statement such as '[...] a system for communicating' - to define language «[...] with a definition you are pretty sure is accurate and complete [...]» (23) Realizing that language does not live in a vacuum, nor-along with linguists such as Chomsky (2000) and Pinker (1994)—does it simply boil down to «[...] an 'organ' that just grows, or an 'instinct [...]'» (Van Lier, 2004: 32), has led me to share a number of postmodernist postulates connected to the philosophical beliefs and pedagogical research of 21 st century sociolinguists, especially M. Halliday's functional perspective (1978, 1990, 2001) and L.S. Vygotsky's sociocultural theory $(1962,1978)$. Building on the Russian psychologist's insights and quoting J.P. Lantolf (2000: 251), Leo van Lier (2004) writes, in the introduction to the second chapter of his overarching work, The Ecology and Semiotics of Language Learning. A Sociocultural Perspective, that the term «ecology» refers

[...] to the totality of relationships of an organism with all other organisms with which it comes into contact. Its core meaning relates to the study and management of the environment (ecosphere, or biosphere) or specific ecosystems. However, it is also used to denote a worldview that is completely different from the scientific or rational one inherited from Descartes, which assumes that it is the right of the human race to control and exploit the earth and all its inanimate and animate resources (the anthropocentric worldview) The ecological worldview is, by contrast, ecocentric or geocentric, and it assumes, similar to the belief systems of indigenous peoples, that 
humans are part of a greater natural order, or even a great living system, Gaia (the living earth; see Capra, 1996; Goldsmith. 1998; Lovelock, 1979; as well as the indigenous peoples of North and South America and elsewhere). (Van Lier, 2004: 3)

From this new perspective, he advances, as quoted, an ecocentric or geocentric worldview as «[...] humans are part of a greater natural order, or even a great living system, Gaia (the living earth [...]» (ibid.) This new view of deep ecology, launched by the Norwegian philosopher Arne Naess (1989), does not simply aim to investigate and fix environmental problems: «The deep way addresses the underlying causes by examining them critically and advocating deep changes» (Van Lier, 2004: 21). Its range and very nature, thus, are provisional and amply based on research.

Van Lier (2004) grounds his ecocentric vision in firm theoretical underpinnings that counter the Cartesian worldview of experimental science. He mentions Reed's (1996) concept of psychology as «[...] a science of values instead of a science of causes, a science of meaning instead of a science of mechanisms» (Van Lier, 2004: 166). Consistently, the ecological approach rebuts the notion that science is to be neutral and value-free. The Dutch scholar propounds a critical perspective for language ecology which, along with Reed's science of values, «[...] must be intervention and change oriented» (168). Such a critical, ethical and committed stance seems warranted by Van Lier's allegiance to the theory of chaos and complexity seen as a new starting point for language ecology. The alternative to the linear perspective of causes and effects, boundaries and dichotomiesnature versus nurture, competence versus performance, langue versus parole, macro versus micro-is thus a holistic vision of closely-interwoven and interacting mind, body and context: «Chaos/complexity encourages us to see complementarities (interactions) instead of dichotomies; the interactions between complementary perspectives are the key focus of research, avoiding the entrenchment of theories into one extreme position or the other» (198). This vantage point rejects «simple solutions to complex problems» (LarsenFreeman, 1997:158) often defended ad absurdum. In the end, apparently divergent theories and incompatible views may often accrue to «[...] windows through which we are better able to see reality» (Natsoulas, 1993). The chaos/complexity perspective posits the inherent instability of all complex systems. Van Lier (2004) explains that «Basically, the learner's interlanguage is an unstable language situated in an unstable linguistic environment, including the unstable target language» (199). In the theory, the importance of detail, like the smallest changes in the learner's interlanguage, is highlighted as it «[... may set in motion a far-reaching restructuring of the learner's interlanguage, the emergence of a whole array of new patterns» (ibid.). The chaos/complexity outlook, then, implies a holistic perception of reality as «The whole cannot be explained on the basis of the parts.

Therefore, any analysis of details must be intimately and continually connected to the whole. The detail must project to the whole, as it were» (ibid.).

What is, then, language ecology? Today's interpretations range widely:

a) Many researchers, such as Denison (1982) and Nelde (1987), use ecology simply as a reference to, or metaphor of «context» or «language environment» to embed 
language-related issues in (macro or micro) sociolinguistic, educational, economic or political settings. The purpose is to avoid decontextualizing language and situate language study, instead, in some form of context.

b) Others have devised specific definitions and sub-categories, for example articles in Fill and Mühlhäusler (2001); Mufwene (2001); Mühlhäusler (1996, 2003a); and two pioneers Jørgen Chr. Bang and Jørgen Døør (2008).

Peter Mühlhäusler (1996) gives prominence to the wider, non-linguistic implications and active commitment of language ecology: «The ecological metaphor in my view is action oriented. It shifts the attention from linguists being players of academic language games to becoming shop stewards for linguistic diversity, and to addressing moral, economic and other 'non-linguistic' issues» (2). Skutnabb-Kangas and Phillipson (2001: 1) subscribe to Wendel's (2005) definition of language ecology: «The ecological approach to language considers the complex web of relationships that exist between the environment, languages and their speakers» (51). Here the term environment encompasses the physical, biological and social spheres and the two critical linguists observe that many sociolinguists only pay lip-service to the physical and biological environments (Skutnabb-Kangas \& Phillipson 2001: 1).

Now language is not something to unpack and study per se, as for mainstream linguistics, nor is the concept of social environment propounded by sociolinguistics entirely consistent with language ecology: «Language exists only in the minds of its users, and it only functions in relating these users to one another and to nature i.e. their social and natural environment» (Haugen, 1972: 325). «The ecology of language» paradigm, then, sees language not as a structure of phonological, syntactic and lexical elements, but as a dynamic force which plays an important role in the interaction between cultures as well as between thought systems and the world. Jean Louis Calvet (2006) builds upon the communicative vision of language as a social practice- «Language is not an object that can be considered in isolation, and communication does not simply occur by means of sequences of sounds [. . .] language [. . .] is a social practice within social life, one practice among others, inseparable from its environment [...]»(22)—to explain his notion of «ecolinguistic system» where languages creatively interact with the environment:

The basic idea is thus that the practices which constitute languages, on the one hand, and their environment, on the other, form an ecolinguistic system, in which languages multiply, interbreed, vary, influence each other mutually, compete or converge. This system is in interrelation with the environment. At every moment language is subject to external stimuli to which it adapts. Regulation, which I will define as the reaction to an external stimulus by an internal change which tends to neutralize its effects, is thus a response to the environment. This response is first and foremost the mere addition of individual responses--variants that, over time, lead to the selection of certain forms, certain characteristics. In other words, there is a selective action of the environment on the evolution of language [...]. (24)

The concept of the eco-system, which has become current in the ecolinguistics of the Haugenian tradition, was first introduced by A.G. Tansley in 1935, and then transferred to the relation between language and the world (Tansley, 1935: 284-307): 
«Language world systems», as they are called in ecolinguistics, are cultural systems created in an evolutionary process. The interaction within these systems occurs in such a way that languages on the one hand influence - and even construe - the world for us, but on the other hand they are shaped by their environment, e.g. the situational context, the current trends of thought, etc. Again, there is a tendency to stress the threat under which these language world systems are in our modern world, in which economy is placed high above ecology, a threat which specifically concerns the creativity of languages and diversity of their means of expression. (Block de Behar et al. 2009: 187)

Eco-critical discourse analysis has been, in this regard, instrumental in anchoring language ecology in real-world concerns and understanding through the application of critical discourse analysis to texts about the environment and environmentalism. Its objective is to expose hidden suppositions and hidden messages and assess the effectiveness of these in achieving environmental aims (Stibbe, 2012; Harré, Brockmeier \& Mühlhäusler, 1999). Ecocritical discourse examines how types of discourse can affect the future of ecosystems, e.g. the neoliberal economic discourse and the discursive constructions of consumerism, gender, politics, agriculture and nature (e.g. Goatly, 2000; Stibbe, 2004). It does not only aim at disclosing potentially damaging ideologies, but also searches for discursive representations contributing to a more ecologically sustainable society. Eco-critical discourse analysis has broadly similar objectives and techniques to other approaches such as eco-semiotics (Selvamony \& Rayson, 2007), environmental communication and eco-criticism.

Overall, ecolinguists criticize the Saussurian divide between langue and parole and stigmatize unecological language uses and anthropocentrisms which portray nature from the perspective of its usefulness for humans, trying to expose ideological manipulation of language — growthism, sexism, classism and anthropocentrism - inherent in many languages and language uses. Consistently, they focus their attention on the research area of the relation between linguistic diversity and biological diversity, two phenomena that they aim to preserve. In this sense, ecolinguistics faces a double challenge: on the one hand, to investigate the contacts between languages in both society and the human mind, and explore the causes and circumstances of language diversity with a strong emphasis on saving small and endangered languages; on the other hand, to explore the ecological and unecological elements of language systems, look at the linguistic representation of the environment, and take a critical view of texts relating to the role of humans in the natural world.

Borrowing Dell Hymes' (2003) words to describe a speech community, linguistic ecology can thus be defined as an approach to thinking about language which attempts to see it «steadily as a whole» (33). In order to achieve this holistic view, linguistic ecology tries to integrate many different levels of explanation without privileging any single level in particular. Accordingly, different disciplinary, artistic and mythic perspectives become potential sources of insight making up an extremely complex natural system that in turn combines with the full complexity of the living world through awareness and action in human cultural communities.

Since Haugen (1972) first set the objectives and boundaries of language ecology, there has been plenty of descriptive work on a number of multilingual ecologies (Denison, 1982: 1-16) as well as conceptual refinement (Enninger \& Haynes, 1984: 235-236). Scholarly interest in the discipline has increasingly appeared in the literature in a variety of fields 
and subfields, or, citing Barron, Bruce and Nunan (eds.) (2002), an «[...] infinite world of possibilities for language ecology» (10):

[...] discussion related to cognitive development and human interaction, the maintenance and survival of languages, the promotion of linguistic diversity, language policy and planning, language, language acquisition, language evolution, language ideology, the ecology of (multilingual) classroom interaction and the ecologies of literacy, oracies and discourses. (Creese et al., 2008: i)

\section{THE INTERCULTURAL PLACE OF LANGUAGE ECOLOGY: A FOCUS FOR ACTION IN DIVERSITY}

By the early 1980s, the importance of the notion of language ecology to applied linguistics had become established, especially as concerns the issue of language shift and loss (Mackay, 1980). Haugen's (1972) metaphor has been reasonably successful as a paradigm for investigating the different contacts between languages. The metaphor of language ecology has been imaginatively and extensively connected to the concept of biodiversity and its concern with conserving and maintaining the variety of life forms. Tove Skutnabb-Kangas and Robert Phillipson remind us that «the first serious sociolinguistic attempts to explore linguistic ecology pleaded for linguistics to be grounded in societal context and change» (Skutnabb-Kangas \& Phillipson 2001: 1). Along these lines, writers have creatively and pragmatically described languages/literacies and their speakers in particular kinds of relationships to one another. This has characterized, for instance, Hornberger's (2002b, 2003) ecological approach to multilingual language policies and the continua of biliteracy. The scholar states that the language ecology metaphor «[...] captures a set of ideological underpinnings for a multilingual language policy [...]» (Hornberger, 2002b: 35) and points to how languages exist and evolve in an eco-system along with other languages, and how their speakers «[...] interact with their sociopolitical, economic and cultural environments» (ibid.). According to Raúl Alberto Mora (2014), language ecology studies the dynamics of interaction and coexistence of old and new languages in social contexts. Mora offers a matter-of-fact explanation of such interaction: «As society becomes increasingly more mobile, dominant languages take the place of lesser known or indigenous languages» (ibid.). The common metaphor used for describing language ecology is, again, that of an eco-system aimed at ensuring a balanced survival of all species. In the scholar's view, a language ecology approach looks at power dynamics and issues of equity and human rights as fundamental elements in the social use of languages. The goal of language ecology, then, is to promote an even-handed and harmonious relationship between languages. In particular, the discipline would mean to prevent any form of language dominance as when, for example, the globalized spread of a language may bring on the endangerment of historically important local languages. Countering this, the new ecological perspective aims to work for the empowerment of minority and indigenous languages as the result of increased social interaction with a larger world (ibid.). As regards implementation, Mora (ibid.) especially highlights language learning and teaching. Various other disciplines, however, can use ecolinguistic constructs to develop frameworks for the protection and promotion of local and indigenous languages. Language ecology inspires 
critical views about bilingualism and multilingualism, language policy and planning and language education, especially in developing countries and in relation to the world role of English today (ibid.). As concerns interculturalism, Mora (ibid.) writes that a language ecology outlook can infuse language learning and teaching to make them a tool for intercultural dialogue. The fundamental objective is to counter subtractive bilingualism and linguistic discrimination against minority and indigenous languages, two elements that undermine dialogue on account of the unfair power differential between languages (ibid.). Mora also remarks that language ecology has been informed by and continues to encourage debates about language imperialism and linguistic human rights (ibid.). From its perspective, scholars have discussed the validity of current frameworks to define controversial linguistic constructs like «language», «native speaker», «cultural diversity» and «ethnicity», proposing more inclusive ideas such as «additional languages», «second languages» or «languages in contact». Considering the normative agency of globalization and social mobility, the availability of stronger language ecology frameworks appears instrumental in the survival of many languages. For this purpose, the proactive co-work of interdisciplinary research and advocacy is crucial to any future language policies and curricular initiatives dovetailing with the views and aims of diversity and coexistence (ibid.). Trim's (1959: 9-25) and Haugen's (1971) articles entail multidisciplinarity and build on multilingual scholarship. Indeed, eight works by Trim are in German, six in English and four in French, whereas today's globalization processes have turned academia more monolingual (Skutnabb-Kangas \& Robert Phillipson, 2001).

This short theoretical overview may give a notion of the multifarious, expansive and controversial concerns and potentialities of language ecology. The very distinctions in defining the discipline attest to its provisional nature and status in applied linguistics. However, I should underlie two outstanding elements that make language ecology especially fascinating and worth investigating:

1. Shifting from an anthropocentric, fixed and normalized idea of language, historically geared to Western colonization and its subtractive and homogenizing set of values, to a new geocentric, mobile, multiple and relational notion of diversity, affordances and mutual integration. Ultimately, the ecological shift in linguists' outlook seems to postulate a more world-responsible —individual and societal- rejection of the postcolonial, «scientific», reifying attitude in human/ nature relationships —underlying sociocultural erosion and submersion, linguistic imperialism and linguacultural death and attrition - and the acquisition of a new holistic, geocentric and committed vision for the purpose of an equitable and viable language ecology the world over.

2. Moving from theoretical discussion to practical and diversified action in the various real-world applications of the discipline: from conscientious language policy and planning to situated bi/multilingual and intercultural teaching and learning practices. Regarding this commitment, Mühlhäusler (2010) specifies three main purposes of ecological linguistics:

a) The preservation of a number of smaller languages in a single communication ecology rather than the preservation of the most widely spoken/best documented language. 
b) The offering of a range of sociologically and structurally different languages for second language learners rather than the focusing on a single world language.

c) The inclusion of native speakers and nonspeakers as well as semispeakers in language revival programs (433).

The disruption of the world's ecolinguistic system over the last 200 years, analogous to its age-old environmental balance, is, in the scholar's view, «[...] a result of European expansion with the consequent restriction and destruction of the majority of the world's linguistic ecologies» (434). He fears, with many others, that, if the current trends are not reversed, $90 \%$ of the world's languages may disappear within two generations (ibid.). Mühlhäusler highlights that since Haugen first created the term «language ecology» for description, this phrase has gradually come to mean a focus for action (ibid.). The new perspective denotes, then, «[...] a home in which different communities can coexist, and their diversity is seen as a valuable resource for restoring the disturbed relationship between human beings and their natural environment» (ibid.). He observes that ecological linguistics seems to conflict «[...] with the system-focused and universalist trend in modern linguistics» and that ecologically aware linguists (e.g. the contributors to Fill, 1996) look at «[...] modern linguistics as empirically unsustainable, as irrelevant, and as an obstacle to applied linguistics» (Mühlhäusler, 2010: 434). This position would be also «argued in the first English language textbook on ecolinguistics» (Mühlhäusler, 2003a. In Mühlhäusler, 2010: 434).

In particular, from the perspective of language ecology, language policy and planning, both in its theoretical discussion and concrete applications, has come to spotlight the growing concerns of today's linguistics with its real-world multiple applications: from the top-down, abstract modernization/development models of the early modernist approach - decontextualized frameworks often born of a nation-state mindset and aimed at «efficiency, rationality, and cost-benefit analysis» (Tollefson, 2010: 465) to a bottom-up, concrete, multidisciplinary and exploratory focus on a variety of sociolinguistic realities and allegiances, with a consistent diversity of interpretive keys and operative instruments. What is especially interesting is to note that this shift in perspective, informed by Fishman's $(1968,1972,1974)$ early sociolinguistic investigation, has led to a postmodernist awareness and critical analysis of the sociocultural specifics and macro-and-micro-linguistic needs and expectations of situated actors: post-colonial polities, autochthonous languages, sign languages, dialects, the often controversial place of migrant languages in Western society and the varying, often unpredictable identity and agency of the individual language user towards the perfunctory assumptions and artificially-enforced schemes of «language engineering». Reviewing the chapter «The Golden Age That Never Was» from Jared Diamond's 1991 book, Skutnabb-Kangas (2004) calls attention to «[...] the evidence for people and cultures before us having completely ruined the prerequisites for their own life, beyond repair. They have destroyed their habitats and/or exterminated large numbers of species. This has happened in many places and it makes the 'supposed past Golden Age of environmentalism look increasingly mythical' (Diamond, 1991: 335)» (Skutnabb-Kangas, 2004: 16). Summing up Diamond's factors of damage, she affirms that this occurs when people 
1. colonize an unfamiliar environment;

2. advance along a new frontier;

3. acquire a new technology whose destructive power people haven't had time to appreciate;

4. have centralized states that concentrate wealth in the hands of rulers who are out of touch with their environment (Skutnabb-Kangas 2004: 16).

Her further gloss encapsulates the answers to factors 1-4:

- As we can see, we have the perfect global prerequisites for ruining our planet beyond repair.

— Ad factor 1: Long-established small societies are breaking up, and, with urbanization and migration, people encounter new environments;

- Ad factor 3: New technologies are more destructive than ever and results of biochemical and other experiments (like genetically modified crops) are taken into use before we know anything about the long-term effects on nature or people;

- Ad factor 4: We have growing gaps and alienated elites;

- And ad factor 2: We do not have the new planets to move to when we have damaged this one... (17)

The Danish linguist's wrap-up is lucidly topical: «Researchers have a responsibility not only to produce solid knowledge about the incredible complexities in this transdisciplinary area, but also to act on the basis of the still (probably always?) incomplete knowledge. It has to be today» (ibid.). Ecolinguists, then, «[...] envisage a balanced ecology of languages [...] where interaction between users of languages does not allow one or a few to spread at the cost of others and where diversity - and the implied ability to adapt to different kinds of environment - is maintained for the longterm survival of humankind (as Baker, 2001 suggests)» (Skutnabb-Kangas \& Phillipson, 2001: 14). For this vital purpose, indigenous cultures and languages «[...] need to have better conditions: they need to be transferred from one generation to the next, in families and through schools. Researchers need to understand and challenge the unequal power relationships implicated in the destruction of language ecologies» (14-15). We may ultimately share the critical linguists' concerned focus on the possible destruction of language ecologies and disappearance of the majority of today's languages and, considering that «Today's efforts are completely insufficient»(15), advocate the necessity for urgent and consistent measures.

\section{LANGUAGE ECOLOGY IN THE LANGUAGE CLASSROOM}

As far as language education is concerned, the ecological metaphor is creatively applied to classroom practices by Creese and Martin (2003), who portray classrooms as ecological microsystems where local interactions are linked to wider socio-political ideologies. On a more systematic level, Leo Van Lier (2004) argues for a new field of educational linguistics based on a holistic and transdisciplinary role of language in education: «The role of language in education is not limited to first, second or foreign 
language classes, it pervades all of education, in all subjects» (Van Lier, 2004: 2). Warning against the «Academic compartmentalization, the balkanization that Hargreaves talks about (1994) [...]», he clearly states that «All education is language education, since language is a defining quality of what it means to be human» (Van Lier, 2004: 2). He focuses on «[...] the dynamic and central role that language plays $[\ldots] »$ and sets out to show «[...] how a more integrated and holistic view of language and education can give a deeper understanding of the nature of education» (ibid.). His ecological approach to language learning, which builds on a far-reaching pedagogical tradition from Spinoza to Bakhtin, from Vygotsky to Halliday-, exploring and incorporating the interrelationship of «[...] practice, research and teaching in equal measure» (Van Lier 2010: 3 ) and looking at «[...] both the macro and the micro sides of the ecological coin [...]» (Van Lier 2004: vii), and the central role of «[...] work, academic, professional and pedagogical [...]»(Van Lier, 2010: 3), has an overarching and comprehensive part in the development of language ecology. Especially noteworthy is his idea that theory should not be separated from practice and that ecology strives to overcome the «[...] conflicts and friction between theoretical and practical pursuits», since, «Although firmly grounded in theory and science, it is a very practical approach to real-life phenomena» (ibid.). Hands-on daily experience instigates, in particular, his notion of individual learner variability and the need to customize teaching practice:

A teacher might proudly announce: «I treat them all the same.» But children -learners of all ages for that matter - are all different, so that equal treatment is surely a doubtful pedagogical practice. There are many differences among learners that are relevant to their educational opportunities in general, and their classroom learning opportunities in particular. A good teacher understands the learners, and this means taking the differences into account. (Van Lier, 2004: 7)

Consistently, in a societal key, «However, there is also variability at a much more macro level: educational systems, far from being the equalizers that policy makers suggest they are, actually manufacture inequalities across regional and socio-economic fault lines» (ibid.). The conclusion perceptively extends to many and diverse educational contexts: «Not all schools are created equal in any country, so that school systems both homogenize and select at the same time, however paradoxical this may seem» (ibid.). In view of the fact that «[...] an ecological foundation can give a theoretical strength and pedagogical focus [...]» to the sociocultural theory (SCT) of Bakhtin (1981) and Vygotsky (1962,1978), Van Lier (2004: viii) presents his idea of «perception-in-action» and explores notions such as «self», «identity», «emergence», «affordance» and «scaffolding» which open up new horizons to research and provide «[...] enough food for thought and action to set the stage for lively discussion and principled progress» (ibid.). In conclusion, the purpose of ecological linguistics, in the scholar's view, is to «[...] extend the ideas of Vygotsky in the light of present-day needs and knowledge» (20). The discipline would attempt «[...] to bring SCT into a motivated, wellarticulated framework that accounts for language, semiosis, activity, affordance, self and critical action» (20). The ultimate aim is to offer «[...] a worldview that rejects the Cartesian dualist, anthropocentric tradition (something that SCT does not do explicitly) and proposes an alternative quality-based pedagogy» (ibid.). 
A key concept in the study of language ecology is the idea of diversity within specific socio-political settings where the processes of language are indexical of, and so reflect, but also create and challenge, particular hierarchies and hegemonies, irrespective of their mutability. Now language, literacy and learning are crucial to an understanding of education from two different perspectives:

a) Looking at education and classroom practice as situated and localized.

b) Zeroing in on schools and interactive classrooms as part of a bigger and more powerful polity in which ideologies serve to reproduce particular power relationships.

Concerning the former (a), Van Lier (2004) holds that diversity «[...] relates to the ways different learners learn, and what that means for the teacher, diversity addresses the value of having different learners and teachers in a class (or school), and in more general terms, different kinds of people in a society, rather than a homogeneous population, however defined» (7). It is interesting to note that the Dutch scholar wrote his quoted book shortly after «No Child Left Behind» was approved and signed into law by President George W. Bush on the 8th January 2002, when the Title VII Bilingual Education Act was eliminated and a radical one-size-fits-all high-stakes testing system reinforced a mono-cultural, decontextualized predominance of standard English on a multi-ethnic and multicultural variety of English language learners, placing the blame of assessment failure on the individual school or teacher instead of the system itself, which denied support for a child's bilingualism (Baker, 2011). Now the construct of diversity comes to have a pivotal role in ecolinguistic thought and practice as a committed rebuttal of blind homogenization. The metaphor of biodiversity recurs in Van Lier's assertion:

In biology, diversity is essential in an ecosystem, and in the same way, a diverse society (in terms of language, ethnicity, religion, interests, etc.) may be healthier in the long run than a homogenous one. In addition, the language to be learned (whether L1 or L2) is presented as one that is not one monolithic standardized code, but a collection of dialects, genres and registers. It is often tacitly assumed that learners would be confused by being presented with a diversity of dialects, cultures, social customs, but it can be argued that more confusion ultimately results from the presentation of a homogeneous language and a single speech community, generalizations that in fact do not exist (Van Lier, 2004: 7)

There he reaffirms the holistic validity of multilingual education: «With appropriate language and learning awareness activities, learners should be perfectly capable of understanding diversity, since it will be easy to establish that it exists in the language all around them, at home, in the community, in school, and around the world» (ibid.).

In footnote 5 (p.7), Van Lier qualifies the import of diversity: «In ecological terms, more diversity is not necessarily always better. However, reducing diversity is almost always detrimental to an ecosystem» (ibid.) Though allowing for the «[...] very tricky and loaded subject, one that raises passions rather than rational argument [...]», he puts forward the crucial, alternative variable of «balance» (ibid.). To this effect, an ecological approach to language education rejects «[...] the immediate, short-term, tangible 
effects of instruction» as in the «[...] Standards, national curricula, course materials, accountability [...]» of «No Child Left Behind» and propounds, instead, an ongoing, situated, encompassing process thriving on the long-term constructs of emergence and affordances (11). I should single out, from my English-teaching experience, Van Lier quoting Ludwig Wittgenstein's pithy remark: «There are remarks that sow, and remarks that reap» (Wittgenstein, 1980: 78e):

Classrooms and schools are contexts designed to afford opportunities for learning, and they may be more or less successful at doing this. Learning opportunities can be of a sowing, or of a reaping kind. Which ones are more important, more valuable, deeper, more lasting, and more powerful? Furthermore, do we know (as teachers, as learners) when a learning opportunity is of a sowing or of a reaping kind? How can we tell? I take that in the reaping scenario we can tell, because we hold something in our hand, we can see a point to a specific item, let's say a performance of some kind by the learner, or a number of bubbles correctly filled in on a test sheet. But in the sowing situation we may be unable to tell, the seeds lie hidden beneath the surface, and may or may not bear fruit, at some unspecified time in the future, in some unspecified way. That is too much uncertainty for learners, teachers, administrators, let alone politicians. For all practical purposes then, the sowing side of learning tends to be ignored, and the focus is on reaping, or at best on a souped-up crop cycle. (Van Lier, 2004: 11-12)

Van Lier vocalizes that ecology looks «[...] deeper and further; it will address the notion of the quality of educational experience, as different from the documentation of educational standards». What appears especially difficult, in his view, is to convince educational policy makers of the greater and cheaper learning opportunities of the sowing scenario, while «[...] the pursuit of high standards, linked to mechanisms of accountability via high-stakes tests, does not promote educational quality» (12). The linguist bears out the ultimate purpose of ecological education, which he looks upon as «[...] worthwhile and valuable outcomes in the future» against high-stakes standards accountability and enacted commercialization of education, featuring, in particular, our globalization-levelled society. He calls for a shift in perspective that goes far beyond the US educational context of his day:

We should put aside as immoral any views that consider students only or primarily as economic units (useful and productive citizens -in other words, fodder for a commercial and political machinery, or Foucault's homo docilis, 1977). Good teachers, of course, always see their students as whole persons, but at times they are almost forced into seeing their students as potential test scores, in the name of standards and accountability. An ecological and sociocultural perspective helps to provide a counter-balance and new arguments against the commercialization of schooling. (Van Lier, 2004: 17)

Regarding the latter more general point (b), researchers and practitioners can profit from an ecological perspective to argue for political rights and challenge mainstream views of knowledge and patterns of schooling. Such ideological commitment may entail advocating the «rearrangement of power» (Creese, et al., 2008: ii) in support of minority and indigenous groups and debating how people ply new technologies and existing resources to create new diversity in their literacy and oral practices. Ecolinguists, as mentioned, have brought home to us the proactive nature of the discipline beyond the mere 
description of the relationships between situated speakers of different languages: pulling apart language orders commonly perceived as natural, i.e. «unnaturalizing» discourses that look «naturalized» but, in fact, construe a particular power-related ideology. The purpose is to clarify «[...] what kinds of language practices are valued and considered good, normal, appropriate, or correct [...]» in particular classrooms and schools, and who are likely to be the winners and losers in the ideological orientations (Heller \& Martin-Jones, eds., 2001: 2). Capitalizing on such insights, Hornberger (2002b) observes that «[...] multilingual language policies are essentially about opening up ideological and implementational space in the environment for as many languages as possible [...]» (30)

Connected to the multifaceted construct of diversity is the much-investigated problem of medium of instruction. This is now a major, and sensitive, issue for language-in-education planners, as many relevant cases follow from globalization and internationalization. The choice of a learning medium is closely intertwined with issues of power and socioeconomic differential. In Bangladesh, for example, this has produced a social and linguistic divide with parallel streams of English and Bangla instruction (Hamid \& Jahan, 2015). At the university level, in particular, programmes of study are being offered in world languages like English to attract international students and improve local students' English proficiency (Ali, Hamid \& Moni, 2011). The same hypercentric role of English impacts on primary education in Asia, where there is increasing pressure to begin English earlier, or to offer programmes in English (Baldauf, Kaplan, Kamwangamalu \& Bryant, 2012). As in Malaysia and in other parts of Asia, the question of what variety of English should be taught is raised by Schmitz (2012) more generally, and by Vodopiji- Krstanoviæ and Brala-Vukanoviæ (2012). In many other parts of the world, where native English speakers have become a minority and most users of the language will be speaking with other nativized or non-native speakers, there arises the question of which norm should be followed and of whether using some form of English as a lingua franca (ELF) would not be a more appropriate intercultural tool «[...] especially for a multiple native-speaking normed language like English [...] (Revista Brasileira de Linguística Aplicada, April/June, 2012)

\section{AN INDIVIDUAL AND SOCIETAL DILEMMA IN THE EUROPEAN UNION: ENGLISH AS A LINGUA FRANCA OR MULTILINGUALISM?}

Overall, language awareness looks especially important in the laborious making of a European citizenship and is logically linked to the multifarious educational and vocational opportunities promoted by the EU, notably over the past fifteen years after the EU Council's ambitious programme of 'one's mother tongue plus two foreign languages' for every EU citizen (Barcelona, March 2002). A recurring dilemma in the EU, and all the more a crucial question after Brexit, has concerned (1) a de facto acceptance of English as a lingua franca or (2) a wider option of multilingualism. The dilemma has inspired the ideological debate, epitomized by the «entirely dissimilar worldviews» (ibid.) of Robert Phillipson and David Crystal:

Phillipson (1992) coined the term linguistic imperialism, and calls attention to the fact that the dominance of English is threatening to other languages, as it maintains the status of 
inequality between languages, and thus between countries and cultures (p. 65). Crystal (1997) claims that the rapid growth of the English language has its reasons in history (pp.7-8), and concludes that the more powerful and influential a nation is, the more chances it has to make its language acknowledged. (Dombi 2011: 185)

(1) Presumably, few scholars would deny the linguistic and cultural dominance of English. David Crystal (2000) himself has significantly illustrated the plight of most world languages and the risk of extinction to about a half of them. Fiedler (2011: 80) gives a concerned account of the de facto English dominance:

However, it is argued that this situation has led to severe disadvantages for non-Anglophones in general and in academia in particular. As recent research has shown (cf. Carli \& Ammon 2007), they have to invest a great deal of time, money and energy into language learning and may still communicate with difficulty. There is a growing awareness of the dangers caused by the dominance of one language over all other languages. It results in a reduction of discourse patterns and a tendency towards a unilateral approach to research. The prevalent use of English favours Anglo-American ideas and authors and leads to a devaluation of other foreign languages. Furthermore, it provides English-speaking countries enormous additional income. (Grin 2005)

The popularity of English also opens the prospect of a difficulty now that, as mentioned, Britain will eventually leave the EU. On the one hand, the swing towards English underlines the growing problem of the decline of language teaching in British schools and universities. It suggests that the motivation for learning languages among native English speakers weakens when people can speak English wherever in the world they may go (Steve Doughty, Mail Online, 6th July 2014). On the other, Brexit has left Brussels running a union whose real common language is only spoken as a native tongue by the five million native speakers from Ireland and Malta who make up only $1 \%$ of the total EU population, as revealed by Cathleen O' Grady («After Brexit, EU English will be free to morph into a distinct variety», The Guardian, 25th September 2017). Paradoxically, however, English could de facto strengthen its historical function of lingua franca in Europe as a common deterritorialized and denativized instrument for international and intercultural communication.

(2) Concerning multilingualism, findings raise a series of questions about the future of languages in the EU. They also deepen criticism of the way the EU spends an estimated $£ 1$ billion a year translating all of its documents into the 24 official languages of the bloc:

With a permanent staff of 1,750 linguists and 600 support staff, the Commission has one of the largest translation services in the world, bolstered by a further 600 full-time and 3,000 freelance interpreters.

In order to reduce the cost to the tax payer, the European Commission aims to provide visitors with web content either in their own language or in one they can understand, depending on their real needs. This language policy will be applied as consistently as possible across the new web presence. An evidence-based, user-focused approach will be used to decide whether many language versions are required or not. (Official Languages of the EU, 2017)

Linguists have extensively illustrated the multifarious benefits of multilingual education. As regards the EU, in particular, multilingualism has been proved to develop 
a speaker's European citizenship. The role of English, in actuality, appears predominant, but the learning and effective use of all other EU languages are promoted too. There comes the special part played by bilinguals and multilinguals in the closer contact that the internet brings people and business into. Heller (1999a) propounds that «[...] to gain advantage in the new global economy, bilinguals will need to adopt a different concept of their identity» (Baker, 2011: 420). In alternative to maintaining one's heritage language and culture, Heller (1999a, 2002) advocated «[...] a new pragmatic identity for language minorities, which allows them to take advantage of their multiple linguistic and cultural resources to participate in a global economy», arguing that «The nature of the New World economy is an ability to cross boundaries, and many bilinguals are relatively skilled in such behavior» (Baker, 2011: 420). In other terms, bilinguals and multilinguals should be pragmatically capable of choosing one's language, variety and register across the «identity-communication continuum» put forward by Kirkpatrick (2007) Their crucial role is typical of the New World globalized economy: to cross borders, make bridges and be brokers between different monolingual economic and political zones (Baker, 2011). This new part as intercultural mediators appears closely predicated upon preserving one's cultural background. Being aware of one's own heritage culture often means rediscovering and appreciating what Luis C. Moll (1992) calls funds of knowledge: a multifarious variety of heritage social rituals and conventions, household activities and abilities, traditions, stereotypes, including history, literature, science and technology, farming and environmental issues. Apart from multifaceted instrumental motivation, then, the foremost reason for individual learning of a second or third language comes to be intercultural awareness, especially in today's global village. It implies getting to know and interact with different cultural conventions, creeds, customs and rituals mediated by one or several target languages to break down societal and individual stereotypes and thus enhance intercultural sensitivity. It also posits a comparative, critical appreciation of cultural variations through networking with one's endogenous and/or exogenous communities on an everyday basis. This is closely connected to the revitalization of dialects as sociolinguistic varieties of a language spoken in a specific area or region in a country. More often than not, dialects have been looked down on as exclusively-oral, labelled «L» or «low», varieties of a language, in spite of occasional literary output, and consistently submerged by nation-state language policy and planning. The gradual demise of the chauvinistic centralism of nation-states and the construction of supranational institutions has marked a renewed interest in dialects as markers of regional identity and sources of sociolinguistic research. One interesting point would be the extension of EU legal forms of minority protection and empowerment to dialects, together with sign and allochthonous, i.e. migrant, languages.

Since society at large is made up of individual citizens, mainstream language policy and planning, on a macrosociological level, interacts with individual behaviour. The rise of standards in modern times out of medieval fila, the attrition and death of minority and lesserused languages and the very prevalent use of three prestigious working languages within the EU's institutions boil down to a set of social practices, or discourses, by individual speakers. Susan Wright (2004) makes the point that top-down measures may be efficacious - as assumedly attested by the Welsh revival — but, in the end, will need to convince speakers of the «linguistic capital», in Bourdieu's sense (1986), of a certain language. 


\section{LINGUA FRANCA AND MIGRATION IN A MULTICULTURAL SOCIETY: BRIDGING GAPS FOR A NEW INTERCULTURAL UNDERSTANDING}

In English as a Lingua Franca in Intercultural Communication, Judit Dombi (2011) highlights the intercultural necessity of having a lingua franca for effective communication in the EU, which is part and parcel of the new multicultural identity of EU citizens today. The linguist observes that «Nowadays the spectrum of communication has broadened, new channels have been opened up, and the interchange of information, thoughts and opinions is more frequent than ever»(183). In fact, a novel sense of mobility -intercultural, educational, vocational - has inspired EU legislation since the coming out of «The White Paper on Education and Training» in 1995, reaffirmed by the 2003 «Action Plan 2004-2006», the Socrates initiative and then Lifelong Learning 2007-2013 and, lately, by the «Europe 2020» strategy as meaning to achieve «smart, sustainable and inclusive growth» (Communication from the Commission Europe 2020: A strategy for smart, sustainable and inclusive growth. Brussels, 3.3.2010). Yasukata Yano (2006) refers to a new sense of «[...] cross-cultural communication between people who do not share the same tradition, values, ideologies but live in different symbolic and cultural universes» (2). In times of «global networking» and «[...] deterritorialized, hybrid, changing and conflicting cultures, where we are expected to become pluricultural individuals» (ibid.), the language policy and planning of the Council of Europe is seen as «[...] a grand experiment based on plurilingualism and pluriculturalism» (ibid.). $\mathrm{He}$ recalls the three basic principles set down by the Council's Committee of Ministers as its aim of language policy (ibid.):

a) that the rich heritage of diverse languages and cultures in Europe is a valuable common resource to be protected and developed, and that a major educational effort is needed to convert that diversity from a barrier to communication into a source of mutual enrichment and understanding.

b) that it is only through a better knowledge of European modern languages that it will be possible to facilitate communication and interaction among Europeans of different mother tongues in order to promote European mobility, mutual understanding and co-operation, and overcome prejudice and discrimination.

c) that member states, when adopting or developing national policies in the field of modern language learning and teaching, may achieve greater convergence at the European level by means of appropriate arrangements for ongoing co-operation and co-ordination of policies.

Council of Europe $(2001,2)$.

The aim of the Council, thus, is to improve» [...] the quality of communication among Europeans of different language and cultural backgrounds so that freer mobility and more direct contact are accelerated, which in turn will lead to better understanding and closer cooperation» (Council of Europe, 2001: xi-xii, in Yano, 2006: 2).

In spite of recent migration-induced wall-building and globalization-driven protectionism, mobility has, indeed, characterized our «[...] integrated, almost 'borderless' 
Europe [...] to an extent that was unimaginable ten-fifteen years ago» (Dombi 2011: 183). Dombi claims, nevertheless, that, in spite of considerable and concerted effort to streamline multilingualism in the EU, findings have attested that English is the most widely known and desired language to learn, since «[...] $51 \%$ of the EU citizens claim ability to hold conversation in English» and «Seventy-seven percent of EU citizens believe that their children should learn English» (185).

In Holmes and Dervin's recent collection, The Cultural and Intercultural Dimensions of English as a Lingua Franca (2016), Karen Risager analyses the implications of using lingua franca communication as a cultural and intercultural bridge in a world of migrations. She distinguishes between linguaculture and discourse, which flows from language to language across topics, texts and media, via translation and other forms of transformation. Focusing on ELF, the linguist observes that it fully embodies the transnational and transcultural dimension of language via mobility and migration across most world countries. Positing that «[...] all language teaching must transcend the traditional national paradigm of one nation, one language, one culture» (48)—outdated and unreal heritage of a colonial and post-colonial past-, she sets the example of Danish as a lingua franca and asserts that linguistic flows and transnational mobilityfor tourism, occupation, educational purposes, regular and irregular migration-require a different perspective, both in communication and in the teaching and learning of language. She states that multilingual and multicultural fluidity across national borders and continents embraces «[...] all age groups, all social groups and most professions, and it also concerns a large number of languages» (47). Nowadays, apparently, not only big cities and commercial hubs, but also the provinces of most countries have immigrants and residents from many different parts of the world, with a melting pot of languages and cultural heritage. Lingua franca studies, and particularly ELF studies, should look into the multifarious forms of communication resulting from migration. One indisputable fact is that «Lingua franca communication is not culturally neutral; on the contrary, all languages carry linguaculture (culture in language) and all individuals develop their own linguacultural profiles» (ibid.), being lingua franca communication linguaculturally quite diverse. Hence conscientious language teaching aiming at training students to take part in lingua franca communication should overcome the national dogma of institutions and discourses of «one language, one nation, one culture» that seem to surface again these days. Risager maintains that «Other more transnationally oriented goals are becoming more important, for example, global citizenship and critical awareness of cultural and linguistic complexity»(47-48), which are also relevant for other languages. Additional relevant goals in the cultural and intercultural learning and teaching of ELF stand out from Risager's discussion and seem to qualify our EU multilingual and multicultural scenarios: multilingual and multicultural awareness, critical intercultural citizenship and education of the world citizen. Presumably, the nature and scope of such objectives concerning the use and teaching/learning of lingua franca, could work as an effective long-term ecolinguistic counter to the current waves of nation-state chauvinism and wall building. 


\section{A VERSATILE GLOCAL MEDIUM: INTERNATIONAL AND INTRANATIONAL USE OF ENGLISH AS A LINGUA FRANCA}

A case in point of the multifarious and versatile potentiality of English as a lingua franca is its applicability to the Greek context as outlined by Fay, Sifakis and Lytra (2016) in a chapter of the quoted 2016 collection. The authors first stress the necessity to focus on the relevance of cultural and intercultural aspects in the use and teaching/learning of the global medium, rather than the much-debated linguistic aspects, i.e. phonology, lexis, lexico-grammar and pragmatics. They call attention to the fact that the intercultural focus already underlay the discussion of the function of English in the international scientific arena during the late 1950s, citing Hoyle's report on the language use at an international conference on astronomy in the Observer in 1958, as discussed by Close (1959, 1981). There the astronomer vocalized the thorny distinction between native scientists' employmentwith a «[...] far-wider range of vocabulary, syntax, and idiom, and [...] free access to a wealth of allusion, of quotations and sayings that a native speaker would resort to without thinking (cited by Close, 1981: 7)»-and the instrumental scientific use of non-British and non-American English speakers (Fay, Sifakis \& Lytra, 2016: 50-51). The divide, with important pedagogical implications, is reminiscent of Kirkpatrick's threefold distinction between language of communication, identity and culture, and the identity/communication continuum of the language functions (Kirkpatrick, 2007: 10-13), which Crystal views as «[...] complementary, responding to different needs» (2003: 22). Overall, in view of widespread English-mediated interaction in transnational settings and participation in intercultural networks, we might place the use of the language as a lingua franca at the right end of Kirkpatrick's continuum, that which maximizes intelligibility by standard or educated varieties. Yet, applied linguists have begun to probe, too, the real-world communicative power and pliability of ELF, still insufficiently investigated, as integrative and intercultural lingua mundi. The diversified terminology dealt with by Fay, Sifakis and Lytra (2016) and other scholars-English as an International Language, English as a Global Language, English as a lingua franca, English for Intercultural Communication and World Englisheshighlights the in-the-making intercultural and international import of using and teaching ELF in our mobile and multifaceted multicultural society. This is exemplified by the fastchanging sociocultural scenario of Greece. The authors write that «From the 1970s onwards, Greece has seen the arrival of repatriated Greeks from Europe, the US, Canada and Australia as well as immigrants from different countries of origin» (59). This social turnabout, which has changed a migrant-sending into a migrant-receiving country, parallels that of other European polities over the last 20th-century decades and onwards. The arrival of migrants and refugees, in particular, brings dramatically to the fore the weaknesses of many EU statemembers' educational systems and the need for an intercultural/multicultural dimension of language education in Europe. In the late 1990s the Greek Ministry of Education introduced

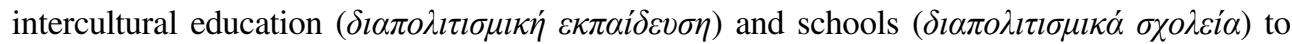
face up to the new challenges and provide a new intercultural curriculum for «[...] young people with special educational, social and cultural needs» (ibid.). The purpose was to further $\pi \circ \lambda v \pi \circ \lambda \imath \tau \iota \sigma \mu \iota \kappa o ́ \tau \eta \tau \alpha$, i.e. multiculturalism, intercultural dialogue and the development of intercultural competence (Androussou, 1996) among «[...] all pupils and teachers, regardless 
of their cultural backgrounds and identities [...]» This new intercultural discourse took stock of the social and cultural diversity of Greek society «[...] in terms of pupils' and teachers' language, gender, religion, culture and socio-economic backgrounds [...]» (60) but clashed with the mainstream monolingual and monocultural «[...] ideology of Greek education which emphasises Greek language learning to the detriment of minority and immigrant languages and cultures (Gogonas, 2010; Lytra, 2007)» (Fay, Sifakis \& Lytra, 2016: 60). The three authors stigmatize the real-world outcomes of Greek intercultural schools that «[...] remain by and large a marginal phenomenon in Greek education $[\ldots] »$ being «[...] confined almost exclusively to specific pupil populations that are perceived as chronically underachieving: children of Roma heritage, of repatriated Greeks and of other immigrant groups» (ibid.). The result appears outstandingly topical and common to many present-day European educational contexts: «Many majority-Greek parents shy away from enrolling their children in schools with a high percentage of 'foreign' pupils» (ibid.). Hence, as in Italy and other European countries, the upshot is educational and sociocultural marginalization in a dramatic conflict between rhetoric and the real classroom: «This not only leads to further ghettoization and marginalisation of these pupils in state education, it also exemplifies the dissonance between intercultural education rhetoric and actual educational practice» (ibid.). Neither did, in the late 1990s, the discourse of multiculturalism in Greek society effectively succeed in destabilizing «[...] the dominant discourse of cultural homogeneity by endorsing cultural diversity within the nation-state $[\ldots] »$ through alternative definitions of «Greekness» (Angelopoulos, 2000). The impending danger, in fact, has been «[...] to slip into exoticization and folkorization of the 'Other' and his/her cultural practices [...]» (ibid.) or, citing Colin Baker (2011), a kind of shallow and factitious «[...] 'ethnic approach', focusing on history, traditions, customs and cultural artefacts in a way that may portray them as 'quaint', 'archaic' or 'strange'»; in other terms, «[...] spectacles for gawking tourists rather than as part of real life, contemporary living cultures» (414). The intercultural dimension of ELF and post-TEFL English language education is thus set against the «boutique multiculturalism» of current Greek discourses of interculturalism but, more conspicuously, it reminds us, as noted, of the apparent lack of a credible intercultural EU policy in the running political turmoil.

A different and more peculiar function of ELF is related to the making of an intracultural dimension of identity. From the perspective of intracultural communication, Henry (2016) throws light on the identity-making reasons for interactants to switch between languages or language varieties in the Chinese context. A surface motive can be the instrumental divide between «mute English», i.e. (mainly written) normative «analytic» competence, for securing entrance to a good university, and «oral English», «experiential» and message-oriented (Johnstone, 2002. In García \& Baker, 2007: 167) for communicating with a native English speaker. In the end, Henry sees no categorical clash between the two varieties as students use «[...] overlapping strategies to achieve multiple competencies» (Henry, 2016: 194). Conversely, shifting from one language to the other has a more profound pragmatic reason: to assert or counter «[...] various forms of identity based on particular language strengths - with the ultimate goal of claiming control of the conversation» (ibid.). Henry emphasizes the creative and strategic use of English in the Chinese scenario: «[...] as an additional linguistic resource to the standard repertoire of Chinese» (Gu, Patkin \& Kirkpatrick, 2014; Sung, 2014a. In Henry, 2016: 194). In other 
terms, changing language, word choice, accent, register and other elements is instrumental in the interactants' playing «[...] with various stances and personae in their speech $[\ldots]$ » through which they index, i.e. affirm, construct or reject, particular identities (ibid.).

Henry presents two forms of indexicality in two distinct speakers' metalinguistic appraisal of their own discursive choices. Ellen, a thirty-year-old English instructor at a local university, categorizes two opposed functions for the two languages: she feels that English can be used for things that are clear, distinct and logical, while Chinese would mediate unclear, blurry and emotional concepts. Hence, as Schieffelin, Woolard and Kroskrity (1998) have noted,

[...] her code-switching reflects a language ideology [...] that partitions logic and emotion between two languages and indexes shifts in her own perception of social identity as she moves back and forth between them. Chinese is the language of emotion, English the language of logic, and her discursive choices emphasise these contrasting aspects of her sense of self. (Henry, 2016: 194-195)

Moreover, her preference for her native tongue to vocalize her own emotions is relevant to ground-breaking research into the cognitive, relational and pragmatic value of emotion in language. To this effect, Alba-Juez, Department of Linguistics, UNED, as well as other scholars (Jornada de Investigación Proyecto Emofundett, 9th October 2015), have distinguished between emotion talk, i.e. the verbal description of emotion, and emotional talk, the explicit utterance of emotions via language. Tracing the controversial relationship between emotion, cognition and language, Alba-Juez singles out emotional ability as a cardinal aspect of bilingual competence and functional/holistic bilingualism.

Other than logic, Henry (2016) observes that English in Shenyang is «[...] associated with identities that are international in orientation; these are configured as Western, cosmopolitan or global» (Henry, 2016: 195). The linguist also reports the views of Jeff, another English teacher at a city-level university in his late twenties, who associates Chinese and English use with two antithetical but integrated communicative styles reminiscent of Ernest Gellner's (1998) divide between romantic communalism and atomistic individualism (Wright, 2004: 244-245). Jeff's choice of English, accordingly, indexes «[...] his claim to membership in the second group of people - those Westerners who 'personalise' everything, who value individuality and want to be 'taken care of' first» (Henry, 2016: 195).

Ellen's and Jeff's language choices - their switching between codes and metalinguistic awareness - thus exemplify divergent and competing worldviews and reflect, in particular, «[...] the hybridity inherent in ELF users' sense of self as positioned between global and local forms of identity (Canagarajah, 2006; Dewey, 2007; Sung, 2014a. In Henry, 2016:195). Realizing such fluid hybridity and mutable sense of self also needs to take stock of the new peculiarities of real-time digital communication featuring the 21th century glocal village, which was simply unimaginable a few decades ago: synchronous or delayed multilingual or language mixing speech-and visual acts with a frequent combination of words, sounds and images for the purpose of functional contextualized expressiveness. 
We may conclude that ELF, by withstanding monocultural and monolingual homogenization, comes to be an international and intranational instrument for intercultural communication, alien from native-speaker normativity and its mathetic ${ }^{1}$ pull, and open to the many voices and educational needs of today's society. Thus, the English language is not only a de facto intercultural global code, i.e. lingua mundi of world science and scholarship; it can also mediate multicultural awareness in its multifarious uses as a lingua franca between members of diverse societies and, primarily, between non-native speakers of English, as set in the teachers' handbook accompanying the new Greek curriculum (Fay, Sifakis \& Lytra, 2016). In spite of the obstacles and constraints «[...] provided by the educational discourses and curricular documents in this Greek context» (64), the spreading use of English as a lingua franca, especially across a prospectively humane and cohesive European framework, can be a flexible and versatile medium for an even-handed and viable language ecology, matching a more generic cultural awareness and skills development with specific cultural awareness of particular topics, (63) «[...] used potentially by any type of English user anywhere in our transnational world of cultural flows of people, products, and ideas as mediated through English» (58).

\section{THE MULTIFACETED MAKING OF A GLOCAL IDENTITY}

More than the construct of culture, that of identity in ELF discourse has been extensively investigated. Findings from ELF use in the most diverse intercultural academic and occupational settings, as suggested by Fiedler (2011), reveal, more than Henry's oppositional identities as indexed by language choice, that no clear dividing line is to be drawn between what Hüllen (1992) distinguished as Identifikationssprachen and Kommunikationssprachen, i.e. 'languages for communication' and 'languages for identification': language as a working process will retain the double function, to a varying degree, in the identity-communication continuum (Kirkpatrick, 2007). Researchers have illustrated «[...] how ELF, as with any language use, is utilized to construct identity, but, in common with much postmodern research in linguistics and outside it [...], the types of identifications constructed are often fluid, emergent, and multiple with participants identifying with a range of different communities» (Baker, 2016: 75). The very meaning of 'understanding' related to ELF settings has been described as «a jointly negotiated and interactional process» (Pitzl, 2015). Recent findings attest to the original employment of native lexicon and idioms by lingua franca users, their ability to co-construct a thirdspace cultural identity which is hybrid, expressive and often tentatively struggling with the structural and idiomatic difficulty of the medium, but creatively reconstructed by the interlocutors' varying contribution to discourse, including humour (Fiedler, 2011: 90). Baker's investigation into the use of ELF in Thailand (Baker, 2009, 2011a, 2011b, $2012 b)$ builds on the notions, variously discussed in the intercultural communication literature, of «global flows», «third places» and «communities of practice» «[...] to refer

\footnotetext{
${ }^{1}$ From ancient Greek $\mu \alpha \theta \eta \tau \iota \kappa o ́ \varsigma$, i.e. relating to knowledge or to the process of learning (English Oxford Living Dictionaries).
} 
to communities and cultures that are salient to the communication at hand and also to create new cultural practices and products (2009: 577-579). Baker's data account for users' «[...] multiple cultural frames of reference in the same conversation [...] moving between and across local, national and global contexts in dynamic ways» (Baker, 2016: 75). ELF researchers, such as Dewey (2007), Ehrenreich (2009) and Seidlhofer (2007; 2011), refer to «communities of practice» (Wenger, 1998) as the «[...] types of dynamic and temporary communities that ELF users may form and identify with» (Baker, 2016: 75). They all underline that these communities are more fluid than originally conceived-of and are better described as «constellations of interconnected practice» (Wenger, 1998, cited in Ehrenreich, 2009: 134). However, Baker (2016) notes that more empirical data are warranted (75). As demonstrated by the cases reported in Holmes and Dervin's book, ELF interaction, therefore, is not relevant to those «[...] binary distinctions between particular languages and cultures characteristic of earlier intercultural communication research» (76). What emerges is a postmodernist «[...] relationship between culture and language entailing fluid, dynamic and multiple viewpoints» (ibid.), although Baker does not reject «[...] more normative influences often associated with national languages and cultures $[\ldots] »$ altogether. He allows for a «[...] tension between normativity and creativity, fixity and fluidity [...]» which conveys the postmodernist understanding of ELF communication debate. Baker highlights the value of emergence and contingency in the ELF relationship between culture and language, which excludes a priori cultural categories and always questions how and why these categories are used (77). Though allowing that this is not unique to ELF, he states that such a constructional and emergent outlook on culture and language induces us to «[...] a necessary critique of how we understand and what we regard as necessary for successful intercultural communication and the associated concept of intercultural competence» (ibid.).

As observed, in glocal multilingual contexts, speakers draw on a multifarious language repertoire to create styles that construct social meanings and, through them, individual identity. This stands out from the global flow of popular culture, in which multilingual style is not simply the vehicle but the message itself (Farr \& Song, 2011: 657). Rap circuits, as illustrated by Pennycook (2010), are a case in point: language mixing is a key feature of these music and lyric circuits as rappers tap a functional variety of resources: from French, English and Haitian Creole in Montreal; Yoruba, Pidgin, English and Igbo in Nigeria; vernacular Cantonese (including a vulgar, largely taboo register) and English in Hong Kong, etc. By using a medley of working-class world language, hip hop is «[...] resistant and oppositional not merely in terms of the lyrics but also in terms of language choice» (Pennycook, 2010: 75).

The glocal spread of English is also epitomized by Asian families with young children who move to English-speaking countries, including Expanding Circle countries (Kachru, 1982). English acquisition comes to be the goal of the family's transnational migration but does not undermine the preservation of heritage language, which continues to mediate the children's ethno-national identity. Rather, English learning adds up to their linguacultural funds as it enables them to enter an imagined cosmopolitan community thus leading to an elitist type of additive bilingualism. These families' adoption of English, therefore, is of accrued value and a key for cosmopolitan membership 
generating multilingual practices and multiple memberships (Chew, 2009: 33-39). Many Asian countries also further English competence by adopting the language as the medium of instruction in order to strengthen their socioeconomic and political capital in the world (Malaysia, Cambodia, India, Nepal, Brunei, Bangladesh, Singapore) or make it an official second language (Japan and South Korea). The usual model for learning is Standard English, which legitimizes the hegemony of the Western variety of the language spoken by the upper middle class in North America and Britain (Tsui \& Tollefson, 2007: 1-21). However, local English varieties emerge and vie with the Western variety in each country, with a range of roles in different contexts. In the main, there is a shift towards the establishment of local varieties of English. In Singapore, for instance, an emergent campaign in 2000 promoted the shift from British Standard English to a local variety of Standard English (LSE) which is thought to be internationally intelligible (Chew, 2007). Chew's survey documents that this variety was favoured over the foreign variety by most Singaporeans. At a basilectal level, Singlish, another local variety only intelligible among Singaporeans, turned out to be used as a marker of Singaporean identity by more than half of the stakeholders (Farr \& Song, 2011: 658). Thus, two opposing forces are in motion: many Asian countries use English as a medium for internationalization, but at the same time they resist its hegemonic influence on their own cultures and national identities. The latter process is exemplified in Japan's national movement for «deconstructing» English, i.e. adopting the language only as a tool so that the values and traditions embedded in the Japanese cultures are retained (Hashimoto, 2007: 27). In such countries, then, the promotion of global English interacts with the maintenance of local languages and cultures, with a resulting variety of linguacultures within one political state (Farr \& Song, 2011: 658).

A different sociolinguistic scenario characterizes North America and Europe, where autochthonous, i.e. regional, and allochthonous, i.e. migrant, languages coexist with national standards. The former languages are indigenous and originated prior to nationstate, e.g. Welsh and Gaelic in Britain; Catalan/Valencian, Galician and Basque in Spain; Native American languages in Canada, the USA and Mexico. The latter result from transnational migration on account of post-colonialism, the late 20th-century historical turnabout and globalization processes, e.g. Turkish in Germany, Algerian Arabic in France and Spanish in the USA. Finally, global English spread into much of Europe and Asia has followed from its dominance as an international medium (ibid.).

Multilingual coexistence in a state implies a hierarchy among languages, and standards generally prevail over local dialects and languages. Yet this depends on contextual factors: global hip hop language, minority language movements and nativized Englishes have produced counter-discourses as opposed to the traditional power of states and elites. On balance, as noted by Farr, Seloni and Song (2010a), «The tension between vernacular usage and the standard taught by schools is of central importance to education generally and to literacy in particular.» 


\section{SHUTTLING BETWEEN DIVERSE ENGLISH-SPEAKING COMMUNITIES WORLDWIDE}

We could finally see ELF as an in-the-making, situational and fluid form of English as an Intercultural Language (EIcL), rather than English as an International Language (EIL), refraining from dogmatic, centripetal observance of native-speaker norms, creatively thriving on native and nativized varieties and their cultural funds of knowledge, and pragmatically suited to the real-life needs of cross-cultural communication and pedagogy. Brian Tomlinson (2006) gives interesting insights in «A Multi-dimensional Approach to Teaching English for the World». He suggests constructing easily-accessible corpora, describing «[...] a Core EIL common to all the varieties of EIL» and developing experiential pedagogy (Harley, 1991), materials and examinations providing «[...] exposure to a rich and varied sample of Englishes being used for a multiplicity of purposes [...]» (147). This comprehensive outlook, focused on the key role of users and reallife interaction, sounds very similar to Nicos Sifakis' (2006) construct of English as an Intercultural Language (EIcL). In «Teaching EIL-Teaching International or Intercultural English? What Teachers Should Know», Sifakis writes that «[...] it is perhaps more useful, when considering real life English language communication, to shift the emphasis from its international usage to its intercultural use by all speakers, native and non-native» (156). The different outlook is also reminiscent of Canagarajah's seminal notion of teaching English for «[...] shuttling between diverse English-speaking communities worldwide, and not just for joining one single community (i.e. a native-speaker community in UK or USA) as we did hitherto [...]» («An Interview with Suresh Canagarajah». In Rubdy \& Saraceni, 2006: 201). This overarching vision encompasses verbal and non-verbal repertoires, intercultural communicative competence, symbolic competence, intercultural awareness, transglossia (García, 2013) and translanguaging (Williams, 1994, 1996) following a C-bound perspective, where $\mathrm{C}$ stands for communication, comprehensibility and culture:

according to which each communicative situation appropriates the use of widely different varieties with elements that are not necessarily readily regularized. In this regard, EIL is normoriented and refers to a finite set of descriptive or prescriptive varieties of world English (cf. Crystal 2003, Smith and Foreman 1997), whereas EIcL is much more expansive: it transcends the linguistic standardization of such communication and refers to those aspects that are situation-specific and cannot necessarily be standardized (e.g. Alred et al. 2002, Byram et al. 2001). (Sifakis, 2006: 156-157)

By «[...] making repairs, asking questions, shortening utterances, changing the tempo of their speech output, etc., (Byram, Nichols \& Stevens, 2001)», learners make their discourse comprehensible and communication successful (Sifakis, 2006: 157). A matter for debate, however, is whether the C-bound route should ultimately conflict with normativity, i.e. the N-bound perspective of «[...] regularity, codification and standardization» (152-153). In other terms, successful intercultural interactants' speech acts can be skilfully geared to the actual conditions of communication, their bilingual or multilingual interlocutors' expectations and localized needs of pedagogic practice, yet exposure to other discourses, strategic resort to paralinguistic means, code-switching, code-mixing and even occasional slip or mistake 
do not necessarily exclude «[...] the usage of some kind of norm.» (158) Significantly, as Sifakis highlights, «[...] that norm can change in the process of communicating, as interlocutors become aware of certain linguistic and non-linguistic elements that make their communication 'tick'» (ibid.). As a matter of fact, many European users of English, such as exchange students and general learners, perform all this uneventfully and to good advantage in the «[...] global networks, structures and flows [...]» (Wright, 2004: 170) of everyday real life. It is part and parcel of these days' global thinking and know-how but, in the end, it has always characterized human communication via interlanguage, which interlocutors invoke to co-build meaning and role-relationships in their situational context.

\section{FINAL REMARKS: LOOKING AT THE PICTURE AS A WHOLE}

In an interview contained in the 2011 European Commission manuscript, François Grin maintains that «[...] unilingualism [...] would be a distinct loss and a gross injustice. It is not more efficient economically - largely because it simply shifts the cost of communication on some people, for the benefit of a few others» (EC manuscript, 2011: 69). Rejecting unilingualism, he advocates turning multilingualism to good account and protect cultural diversity through a better use of technology. He wraps up the interview with a pithy observation: «It is just that instead of looking at one narrow aspect of the picture, we have to look at the picture as a whole» (70). In an ecolinguistic key, a more consistent ecological awareness, also urged by the universally felt threat of imminent global warming, and its pernicious effects, seems to imply, as viewed, a different, non-anthropocentric, verbalization of natural phenomena. When thinking of the overpowering part of global lobbies and cunning ways of consumerist advertisement worldwide, the formulation of real-world phenomena and events may sound minor or unimportant, yet, as illustrated by Halliday (2001), it may form the basis for a new world-friendly outlook and action these days. Since «Monolithic solutions are no longer viable» (Lingua Franca: Chimera or Reality?: 50), today's knowledge society will require ever more flexible responses, both pragmatic and far-sighted, to cope with the constant tension between local and global needs and identities (ibid.), which has led to the dual construct of glocalization. Thus, in order $«[\ldots]$ to transmit information and ideas across language borders $[\ldots] »$ in a $«[\ldots]$ dynamic world system of languages [...]», as Mark Fettes (2003: 37-38) says, with equity, efficiency, and sustainability, a variety of strategies could be invoked and flexibly geared to the specific sociocultural circumstances: «[...] acquisition of other languages, translation and interpretation, various forms of localization and the development of innovative tools like inter-comprehension or machine translation» (51), but, also, individual situated recourse to code-shifting, code-mixing and non-verbal repertoires. By the same token, what seems today a common-sense, «necessary but not sufficient» (Grin, 1999) baseline skill may become a real-world, empowering and ideologically-flexible English competence in this dynamic, intercultural and integrated world of ours.

To date, the outcome of the ecological outlook in linguistics has warranted careful documentation. We may wonder, in other terms, whether the European call for subsidiarity and devolution, the protection and promotion of regional identities and languages, and 
the outlook on multicultural and multilingual heritage as a resource instead of a burden could be workable or should only sound like wishful thinking. Ultimately, a feasible and efficient policy could promote multilingualism, protect regional and lesser-used languages, often marginalized by nation-state centralism, and thus augment their symbolic capital, but also further English-language competence and the real-world role of English as a lingua franca in Europe. Along with the obvious instrumental elements of transcendence, a EU English - or several varieties - might grow up in time, with the phonological, lexico-grammar and idiomatic flavour — as Chinglish in China, Singlish in Singapore or the Indian variety - of a fully-fledged natural language learnt as a first language, like creoles, or Hiddish to young Israelis, by future generations. This new language might eventually evoke a new unified European identity and become the EU's supranational language for intercultural communication being a major cut in expenditure and an indispensable common tool for every European. It would probably be a simplified, rather artificial, language at the beginning, necessarily empty of idiomatic features, yet open to the variegated diversity of phonological and lexico-grammar peculiarities of its speakers' native tongues. It goes without saying that all other languages — national, regional, allochthonous and sign languages - could continue to be used in specific sectors and domains and preserved for identification purposes. We can even suppose that, in spite of all forms of nationalism and chauvinism, a EU variety or regional varieties of English might eventually supersede nation-state languages, as pluricentric Latin superseded pre-Roman tongues in Mediterranean Europe. But just as these languages lived on as the substrata of the new Romance languages, English hegemony would not necessarily entail submersion, or removal, of the sociocultural heritage and funds of knowledge handed down and mediated by the original tongues and dialects.

The issues of language and ecology and ecology of languages continue to be well represented at symposia and conferences in general and applied linguistics, with a growing number of younger scholars, particularly linguists from Europe, such as Döring, (2002), as attested by the proceedings of the Thirty Years of Language and Ecology Conference. (Fill, Penz \& Trampe, 2002) Empirical research might examine the viability of an intercultural, equitable and inclusive language ecology in a new united Europe inspired by biodiversity and human rights awareness, which may build bridges instead of walls between cultures, languages and religions. Taking into account the specific living conditions of each language - heritage languages, migrant languages, dialects and lingua francas-, not easily changed by superimposed models, we may advocate a new ecolinguistic outlook on and real-world attention to those multifarious scenarios, with a critical eye and conscientious respect for language diversity and the ultimate choice of communities and individuals. This commitment appears especially crucial in this day and age of concrete and symbolic wall building and sociocultural intolerance. What still remains to be investigated is whether the effects of this turn will bring out a paradigm shift in linguistics and whether the ecological perspective will keep its promise to contribute significantly to supporting and improving the health of endangered languages, the natural environment (Mühlhäusler, 2010) and more tolerant intercultural understanding. The jury is still out, but, presumably, who is going to have the last word will not be top-down policy, but the bottom-up daily choices of individual Europeans. 


\section{REFERENCES}

Ali, N.L., Hamid, M.O. and Moni, K. (20I I). English primary education in Malaysia: policies, outcomes and stakeholders' lived experiences. Current Issues in Language Planning 12 (2), pp. 147-166.

Alred, G., Byram, M. and Fleming, M. (eds.) (2002). Language in Intercultural Communication and Education. Clevedon: Multilingual Matters.

ANDRoussou, A. (1996). An intercultural dimension in intercultural practice. In A. Vafea (coordinator) The Multicultural School: An Experience of Intercultural Education through Art, Athens: Nisos, pp. 11-23.

BAKER, C. (200I). Review of Tove Skutnabb-Kangas, Linguistic genocide in education - or worldwide diversity and human rights? Journal of Sociolinguistics 5 (2), pp. 279-283.

BAKER, C. (2OI I). Foundations of Bilingual Education and Bilingualism, 5th edition. Tonawanda, NY: Multilingual Matters /Channel View Publications.

BAKER, W. (2009). The cultures of English as a lingua franca. TESOL Quarterly 43 (4), pp. 567-592.

BAKER, W. (2OI IA). Intercultural awareness: Modelling an understanding of cultures in intercultural communication through English as a lingua franca. Language and Intercultural Communication 11 (3), pp. 197-214.

BAKER, W. (2O I I B). Culture and identity through ELF in Asia: Fact of fiction? In A. Cogo, A. Archibald and J. Jenkins (eds,) Latest Trends in ELF Research (pp. 35-52). Newcastle upon Tyne: Cambridge Scholars.

BAKER, W. (2OI2B). Using online learning objects to develop intercultural awareness in ELT: A critical examination in a Thai higher education setting. British Council Teacher Development Resarch Papers. Retrieved from: http://www.teachingenglish.org.uk/publications

BAKER, W. (20I6). Culture and Language in Intercultural Communication, English as a Lingua Franca and English Language Teaching: Points of Convergence and Conflict. In Prue Holmes and Fred Dervin The Cultural and Intercultural Dimensions of English as a Lingua Franca (pp. 70-89). Bristol/Buffalo/Toronto: Multilingual Matters.

BaKhtin, M. (I98I). The Dialogical Imagination. Austin: University of Texas Press.

Baldauf, R.B., Jr., Kaplan, R.B., Kamwangamalu, N.M. and Bryant, P. (eds.) (2012). Language Planning in Primary Schools in Asia. New York: Routledge Bang, J. Ch. and Døør, J. (2008) Language, Ecology and Society, A Dialectical Approach. Joshua Nash, Sune Vork Steffensen. Retrieved from: http://www.bloomsbury.com/us/language-ecology-and-society-9780826446428/

Barron, C., Bruce, N. and Nunan, D. (eds.) (2002). Knowledge and Discourse. Towards an Ecology of Language. London: Longman.

Block de Behar, L., Mildonian, P., Dijan, J.M., Kadir, D., Knauth, A., Romero Lopez, D. and Seligmann Silva, M. (2009). Comparative Literature: Sharing Knowledges for Preserving Cultural Diversity, Volume III, Oxford, UK: EOLS Publishers/UNESCO.

Bourdieu, P. (I982). Ce que parler veut dire. Paris: Fayard.

Bourdieu, P. (I986). The forms of capital. In J. Richardson (ed.) Handbook of Theory and Research for the Sociology of Education. New York: Greenwood, pp. 241-258.

Bourdieu, P. (I99I). Language and Symbolic Power. Cambridge: Polity Press.

Byram, M, Nichols, A. and Stevens, D. (eds.) (200I). Developing Intercultural Competence in Practice. Clevedon: Multilingual Matters.

Calvet, J.L. (2006). Towards an Ecology of World Languages, translated by Andrew Brown. Cambridge: Polity Press.

Canagarajah, A.S. (2006). Ethnographic methods in language policy. In T. Ricento (Ed.), An Introduction to Language Policy: Theory and Method, Oxford: Blackwell, pp.153-169. 
Canagarajah, A.S. (2006). An Interview with Suresh Canagarajah. In R. Rubdy, M. Saraceni and contributors, English in the World. Global Rules, Global Roles (pp. 200-211). London, New York: Continuum.

Carli, A. and Ammon, U. (eds.) (2007). Linguistic inequality in scientific communication today. AILA Review 20.

CApra, F. (1996). The Web of Life: A New Scientific Understanding of Living Systems. New York: Anchor Books.

Chew, P.G. (2007). Remaking Singapore: Language, culture and identity in a globalized world. In A.B.M. Tsui, and J.W. Tollefson (eds.), Language Policy, Culture and Identity in Asian Contexts (pp. 73-94). Mahwah, NJ: Lawrence Erlbaum.

Chew, P.G. (2009). In pursuit of linguistic gold: mothering in a globalized world. English Today 25(2), pp. 33-39.

Сноmsкy, N. (2000). New Horizons in the Study of Language and Mind. Cambridge: Cambridge University Press.

Close, R.A. (1959). English as World English. The Linguist's Review 1 (6), pp.116-117.

Close, R.A. (I98I). English as a Foreign Language: Its Constant Grammatical Problems. London: HarperCollins.

Creese, A. and Martin, P. (eds.) (2003). Multilingual Classroom Ecologies, Multilingual Matters, Clevedon.

Creese, A., Martin P. and Hornberger, N.H. (eds.) (2008). Encyclopedia of Language and Education, 2nd Edition, Volume 9: Ecology of Language, i-vi, Springer Science+Business Media LLC.

Crystal, D. (1997). English as a Global Language. Cambridge: Cambridge University Press.

Crystal, D. (2003). English as a Global Language (second edition). Cambridge: Cambridge University Press.

Crystal, D. (2000). Language Death. Cambridge: Cambridge University Press.

Denison, N. (I982). A linguistics ecology for Europe. Folia Linguistica 16 (1), pp. 1-16.

Dewey, M. (2007). English as a lingua franca and globalization: An interconnected perspective. International Journal of Applied Linguistics 17 (3), pp. 332-354.

Diamond, J. (I99I). The Rise and Fall of the Third Chimpanzee. London: Vintage.

DöRING, M. (2002). 'Vereint hinterm Deich'-Die metaphorische Konstruktion der Wiedervereiningung in der deutschen Presseberichterstattung zur Oderfut, [Unified behind the Dyke-The Metaphorical Construction of Unification in German Press Reports about the River Oder Flood] 1997. In A. Fill, H. Penz, and W. Trampe (Eds), Colourful Green Ideas Bern: Peter Lang, pp. 255-273.

DombI, J. (20I I). Bulletin of the Transilvania University of Braşov. Series IV: Philology and Cultural Studies, Vol. 4 (53) No.1.

Doughty, S. (6TH July 20I4). English is the lingua franca of Europeans as two thirds speak the language which has squeezed out all its rivals, on Mail Online. Retrieved from: http://www. dailymail.co.uk/news/article-2436051/English-lingua-franca- Europeans-thirds-speak-languagesqueezed-rivals.html

EHRENREICH, S. (2009). English as a lingua franca in multinational corporations: Exploring business communities of practice. In A. Mauranen and E. Ranta (eds.) English as a Lingua franca: Studies and Findings (pp. 126-151). Newcastle upon Tyne: Cambridge Scholars Publishing.

ENNINGER, W. and L. HAYNES, (I984). Language ecology-a revived paradigm? In W. Enninger, W.W. Haynes and L. Haynes (Eds.), Studies in Language Ecology (pp. 235-236). Wiesbaden, Germany: Steiner.

EU Commission (I995). The White Paper on Education and Training. Teaching and Learning Towards the Learning Society. Retrieved from: http://europa.eu/documents/comm/white_papers/pdf/ com95_590_en.pdf 
EU Commission (2003). Promoting language learning and linguistic diversity. An action plan 200406. Brussels: COM. Retrieved from: http://www.saaic.sk/eu-label/doc/2004-06_en.pdf

EU Commission Lifelong Learning Programme (LLP) (2007-2013). Retrieved from: http://ec. europa.eu/education/lifelong-learning-programme_en

EU COMmission Europe 2020 (3RD MARCH 20IO). A strategy for smart, sustainable and inclusive growth. Communication from the Commission. Brussels, 3.3.2010 COM (2010) 2020 Retrieved from: http://ec.europa.eu/eu2020/pdf/COMPLET\%20EN\%20BARROSO\%20\%20\%20007\%20\%20Europe\%202020\%20-\%20EN\%20version.pdf

EU COMMISSION (MANUSCRIPT COMPLETED ON I I JANUARY 2OI I). Directorate-General for Translation. Studies on translation and multilingualism. Lingua Franca: chimera or reality? Retrieved from: http://cordis.europa.eu/fp7/ict/language-technologies/docs/lingua-franca-en.pdf

EU Commission (20I7). Official Languages of the EU. Retrieved from: http://ec.europa.eu/education/ official-languages-eu-0_en

EU Council of Europe (200I). Common European Framework of Reference for Languages: Learning, Teaching, Assessment. Cambridge, UK: Cambridge University Press.

Farr, M., Seloni, L. and Song, J. (20IOA). Ethnolinguistic diversity in language and literacy education. In M. Farr, L. Seloni and J. Song, Ethno- linguistic diversity and education: language, literacy, and culture (pp. 1-20), New York: Routledge.

FARr, M. and Song, J. (20I I). Language Ideologies and Policies: Multilingualism and Education, Language and Linguistics Compass 5/9 (pp. 650-665). Blackwell Publishing Ltd.

FAy, R., Sifakis, N. and Lytra, V. (20I6). Interculturalities of English as a Lingua Franca: International Communication and Multicultural Awareness in the Greek Context. In Prue Holmes and Fred Dervin The Cultural and Intercultural Dimensions of English as a Lingua Franca (pp. 50-69). Bristol/Buffalo/Toronto: Multilingual Matters.

FETtes, M. (2003). The geostrategies of interlingualism. In Languages in a Globalizing World, edited by Jacques Maurais and Michael A. Morris, Cambridge: Cambridge University Press.

FiedLer, S. (20II). English as a lingua franca - a native-culture-free code? Language of communication vs. language of identification. Apples - Journal of Applied Language Studies, Vol. 5, 3, pp. 79-97.

FILL, A. (ed.) (I996). Sprachökologie und Ökolinguistik [Language Ecology and Ecolinguistics]. Tübingen: Stauffenburg.

Fill, A. and MüHlhäUSLER, P. (eds.) (200I). The Ecolinguistics Reader: Language, Ecology and Environment. London: Continuum.

Fill, A., Penz, H. and Trampe, W. (eds.) (2002). Colourful Green Ideas. Bern: Peter Lang.

Fishman, J.A. (ed.) (I968). The sociology of language. In J.A. Fishman (Ed.), Readings in the Sociology of Language (pp. 5-13), vol. 1. The Hague: Mouton.

Fishman, J.A. (ed.) (1972). The Sociology of Language. Rowley, MA: Newbury House.

Fishman, J.A. (ed.) (1974). Advances in Language Planning. The Hague: Mouton.

Foucault, M. (1972). The Archeology of Knowledge and the Discourse on Language. (translated from the French by A.M. Sheridan Smith) New York: Pantheon Books.

Foucault, M. (1977). Discipline and Punish: the Birth of the Prison. New York: Pantheon.

Foucault, M. (1980). Power/knowledge. New York: Pantheon Books.

Foucault, M. (1985). The use of pleasure: History of sexuality, vol. 2. New York: Vintage Books.

García, O. (20I3). From disglossia to transglossia: Bilingual and multilingual classrooms in the 21st century. In C. Abello-Contesse, P. M. Chandler, M. D. López-Jiménez, and R. Chacón-Beltrán (eds.),

Gellner, E. (1998). Language and Solitude: Wittgenstein, Malinowsky and the Habsburg Dilemma. Cambridge University Press. 
Goatly, A. (2000). Critical Reading and Writing: an Introductory Coursebook. London: Routledge.

Gogonas, N. (20I0). Bilingualism and Multilingualism in Greek Education: Investigating Ethnic Language Maintenance Among Pupils of Albanian and Egyptian Origin in Athens. Newcastle Upon Tyne: Cambridge Scholars Publishing.

GoldSmith, E. (1998). The Way: an Ecological Worldview (second edition). Athens: University of Georgia Press.

Grin, F. (I999). Language spread and linguistic diversity, in M. Kontra, R. Phillipson, T. Skutnabb Kangas and T. Varady (eds.), Language: a Right and a Resource. Budapest: Central European University Press.

GRIN, F. (2005). Linguistic human rights as a source of policy guidelines: A critical assessment. Journal of Sociolinguistics 9 (3), pp. 448-460.

Gu, M., PAtKIn, J. and KirKPatrick, A. (20I4). The dynamic identity construction in English as lingua franca intercultural communication: A positioning perspective. System 46, pp. 131-142.

HAECKEL, E. (I866). Generelle Morphologie der Organismen [General Morphology of Organisms], G. Reimer, Berlin. Translation by Brewer, R. (1988). In Oxford Handbook of Applied Linguistics (p. 421), second edition edited by R.B. Kaplan (2010), Oxford: Oxford University Press.

Halliday, M.A.K. (1978). Language as Social Semiotic. London: Edward Arnold.

Halliday, M.A.K. (I990). New ways of meaning: a challenge to applied linguistics. Greek Applied Linguistics Association, Journal of Applied Linguistics (Ninth World Congress of Applied Linguistics Special Issue), vol. 6, pp. 7-36.

Halliday, M.A.K. (200I). New ways of meaning: the challenge to applied linguistics. In A. Fill and P. Mühlhäusler (eds.), The Ecolinguistic Reader: Language, Ecology and Environment (pp. 175202). London and New York: Continuum.

HAMID, M.O. and JAHAN, I. (20I5). Language, identity and social divides: medium of instruction debates in Bangladeshi print media. Comparative Education Review, Vol. 59, No. 1, February 2015, (pp. 75-101). Published by The University of Chicago Press on behalf of the Comparative and International Education Society. Stable URL: http://www.jstor.org/stable/10.1086/679192

Harley, B. (I99I). Instructional strategies and SLA in early French immersion. Studies in Second Language Acquisition 15, pp. 245-249.

Harré, R., Brockmeier, J. and MühlhäUsler, P. (I999). Greenspeak: a Study of Environmental Discourse. London: Sage.

Hasнiмото, K. (2007). Japan's language policy and the "lost decade". In A.B.M. Tsui and J.W. Tollefson, Language policy, culture, and identity in Asian contexts (pp. 25-36). Mahwah, NJ: Lawrence Erlbaum.

Haugen, E. (I97I). The ecology of language, The Linguistic Reporter. Supplement 25, pp. 19-26. Reprinted in E. Haugen: 1972, The Ecology of Language. Essays by Einar Haugen (pp. 324-329). Dil, A.S. ed. Stanford: Stanford University Press.

Haugen, E. (I972). The ecology of language, based on «The Stigmata of Bilingualism», a lecture given at Brown University, Providence, Rhode Island, USA. In A.S. Kil (Ed.), The Ecology of Language: Essays by Einar Haugen (pp. 324-329) (ed. Anwar S. Dil) Stanford CA: Stanford University Press.

Heller, M. (I999A). Linguistic Minorities and Modernity: A Sociolinguistic Ethnography. New York: Longman.

Heller, M. (2002). Globalization and the commodification of bilingualism in Canada. In D. Block and D. Cameron (eds.) Globalization and Language Teaching. London: Routledge.

Heller, M. and Martin-Jones, M. (eds.) (200I). Introduction: symbolic domination, education and linguistic difference. In M. Heller and M. Martin-Jones, Voices of Authority: Educational and Linguistic Difference. Westport, CT: Ablex Publishing. 
HenRy, E.S. (20I6). The Local Purposes of a Global Language: English as an Intracultural Communicative Medium in China. In P. Holmes and F. Dervin, The Cultural and Intercultural Dimensions of English as a Lingua Franca (pp. 180-200). Bristol/Buffalo/Toronto: Multilingual Matters.

Holmes, P. and Dervin, F. (20I6). The Cultural and Intercultural Dimensions of English as a Lingua Franca. Bristol/Buffalo/Toronto: Multilingual Matters.

Hornberger, N.H. (2002B). Multilingual language policies and the continua of biliteracy: an ecological approach. Language Policy 1 (1), 27-51.

Hornberger, N.H. (2003). Continua of Biliteracy: An Ecological Framework for Educational Policy, Research and Practice in Multilingual Settings. Clevedon, Avon, UK: Multilingual Matters.

HÜLlEN, W. (I992). Identifikationssprachen und Kommunikationssprachen. Über Probleme der Mehrsprachigkeit. [Languages for identification and languages for communication. About problems of multilingualism] Zeitschrift für Germanistische Linguistik 20: 3, pp. 298-317.

Hymes, D. (2003). Foundations in Sociolinguistics: An Ethnographic Approach. Psychology Press.

KaChru, B.B. (ed.) (1982). The Other Tongue: English Across Cultures. Chicago: University of Illinois Press.

KirKPATRICK, A. (2007). World Englishes, Implications for International Communication and English Language Teaching. Cambridge: Cambridge University Press.

Lantolf, J.P. (2000). Sociocultural Theory and Second Language Learning. Oxford: Oxford University Press.

Larsen-Freeman, D. (1997). Chaos/complexity science and second language acquisition. Applied Linguistics 18, pp. 141-165.

Lovelock, J. (1979). Gaia. Oxford: Oxford University Press.

Lytra, V. (2007). Play Frames and Social Identities: Contact Encounters in a Greek Priary School. Amsterdam and Philadelphia: John Benjamins.

Mackey, W.F. (I980). The ecology of language shift. In P. Nelde (Ed.), Sprachkontakt und Sprachkonflikt [Language Contact and Language Conflict] (pp. 35-41). Wiesbaden, Germany: Steiner.

MolL, L.C. (1992). Bilingual classroom studies and community analysis: some recent trends. From Educational Researcher, 21 (2), pp.20-24. Washington, DC: American Educational Research Association. In Bilingual Education. An Introductory Reader (2007) (pp.272-280). Edited by Ofelia Garcìa and Colin Baker, Multilingual Matters Ltd, Clevedon, Buffalo, Toronto.

Mora, R.A. (20I4). Center for Intercultural Dialogue. Key Concepts in Intercultural Dialogue 13: Language Ecology. Retrieved from: https://centerforinterculturaldialogue.files.wordpress. com/2014/05/key-concept-language-ecology.pdf

MüHlhäUSLER, P. ( I996). Linguistic Ecology. London: Routledge.

MühlhäUsler, P. (2003A). Language of Environment, Environment of Language: A Course in Ecolinguistics. London: Battlebridge.

MüHlhäUsler, P. (20io). Ecology of Languages. In R.B. Kaplan, Oxford Handbook of Applied Linguistics (pp. 421-434). Second Edition edited by Robert B. Kaplan. Oxford: Oxford University Press.

Mufwene, S.S. (200I). The Ecology of Language Evolution. Cambridge: Cambridge University Press.

NaEss, A. (1989). Ecology, Community and Lifestyle. Translated and edited by D. Rothenberg. Cambridge: Cambridge University Press.

Natsoulas, T. (1993). Perceiving, its component stream of perceptual experience, and Gibson's ecological approach. Psychological Research 55, 248-257.

Nelde, P.H. (I987). Language contact means language conflict. In G. Mac Eoin, A. Ahlqvist, and C. OhAodha (eds.), Third International Conference on Minority Languages (pp. 33-42). Clevedon, Avon, UK: Multilingual Matters. 
O'Grady, C. (25Th September 2017). After Brexit, EU English will be free to morph into a distinct variety, The Guardian. Retrieved from: https://www.theguardian.com/science/blog/2017/sep/25/ without-uk-influence-eu-english-will-be-free-to-morph-into-a-distinct-variety

OXFORD DictionARIES (20I7). Oxford: Oxford University Press. «Mathetic». Retrieved from: https:// en.oxforddictionaries.com/definition/mathetic

PenNyCOOK, A. (20IO). Nationalism, identity and popular culture. In N. Hornberger and S. McKay, Sociolinguistics and language education 1 (pp. 62-86). Bristol: Multilingual Matters.Phillipson, R. (1992) Linguistic Imperialism. Oxford: Oxford University Press.

PinkeR, S. (I994). The Language Instinct. New York: William Morrow.

PITZL, M.L. (20I5). Understanding and misunderstanding in the common European framework of reference: What can we learn from research on BELF and intercultural communication? Journal of English as a Lingua Franca, 4(1), pp. 91-124.

ReEd, E.S. (1996). Encountering the World: Toward an Ecological Psychology. New York: Oxford University Press.

Revista Brasileira de Linguística Aplicada, vol. 12 no. 2. Belo Horizonte Apr./June 2012 On-line version ISSN 1984-6398. Retrieved from: http://dx.doi.org/10.1590/S1984-63982012000200002

Risager, K. (20I6). Lingua Francas in a World of Migrations. In Prue Holmes and Fred Dervin, The Cultural and Intercultural Dimensions of English as a Lingua Franca (pp. 33-49). Bristol/Buffalo/ Toronto: Multilingual Matters.

SchiefFelin, B.B., Woolard, K.A. and Kroskrity, P.V. (eds.) (1998). Language Ideologies: Practice and Theory. Oxford: Oxford University Press.

Schmitz, J.R. (20I2). To ELF or not to EFL? (English as a lingua franca): that's the question for applied linguistics in a globalized world. Revista Brasileira de Linguística Aplicada, v. 12, n.2, 249-284.

SEIDlhofer, B. (2007). English as a lingua franca and communities of practice. In S.Volk-Birke and J. Lippert (eds.), Anglistentag 2006 Halle Proceedings (pp. 307-318). Trier: Wissenschaftlicher Verlag.

SeIDlhofer, B. (20 I I). Understanding English as a Lingua Franca. Oxford: Oxford University Press. Selvamony, N. and A.K. Rayson (eds.) (2007). Essays in Ecocriticism. New Delhi: OSLE.

SIFAKIS, N. (2006). Teaching EIL-Teaching International or Intercultural English? What Teachers Should Know. Hellenic Open University. In R. Rubdy, M. Saraceni and contributors, English in the World. Global Rules, Global Roles (pp. 151-168). London, New York: Continuum.

SkUtNABB-KANGAS, T. (2004). On Biolinguistic Diversity-linking language, culture and (traditional) ecological knowledge. Invited plenary lecture at the interdisciplinary seminar «At the limits of language», organised by Department of Biology and Department of Linguistics and Philosophy, Universidad Autónoma de Madrid and Cosmocaixa (March 2004).

Skutnabb-Kangas, T. and Phillipson, R. (200I). Language ecology. In Handbook of Pragmatics (pp. 1-19). Eds. Jef Verschueren, Jan-Ola Östman, Jan Blommaert and Chris Bulcaen. Amsterdam and Philadelphia: John Benjamins.

Smith, L.E. and Foreman, M.L. (I997). World Englishes 2000, Honolulu, HI: University of Hawaii Press.

Stibbe, A. (2004). Masculinity, health and ecological destruction. Language and Ecology Online Journal.Retrieved from: file:///C:/Users/Utente/Downloads/mens_health\%20(2).pdf

Stibbe, A. (2012). Animals Erased: Discourse, Ecology and Reconnection with the Natural World. Middletown, CT: Wesleyan University Press.

Sung, C.C.M. (20I4A). English as a lingua franca and global identities: Perspectives from four second language learners of English in Hong Kong. Linguistics and Education, 26, pp. 31-39.

Tansley, A.G. (1935). The Use and the Abuse of Vegetational Concepts and Terms. Ecology 3, pp. 284-307. 
Tollefson, J.W. (20I0). Perspectives on language policy and planning in R.B. Kaplan, The Oxford Handbook of Applied Linguistics (p. 463). Oxford: Oxford University Press, Inc.

Tomlinson, B. (2006). A Multi-dimensional Approach to Teaching English for the World. Leeds Metropolitan University. In R. Rubdy, M. Saraceni and contributors (2006), English in the World. Global Rules, Global Roles (pp.130-150). London, New York: ContinuumTrim, J.L.M. (1959) Historical, descriptive and dynamic linguistics, Language and Speech 2 (1), pp. 9- 25.

Tsui, A.B.M. and Tollefson, J.W. (2007). Language policy and the construction of national cultural identity. In A.B.M. Tsui and J. W. Tollefson, Language policy, culture, and identity in Asian contexts (pp. 1-21). Mahwah, NJ: Lawrence Erlbaum.

VAN LIER, L. (2004). The Ecology and Semiotics of Language Learning: A Sociocultural Perspective. New York: Kluwer Academic.

VAn Lier, L. (20I0). The Ecology of Language Learning: Practice to Theory, Theory to Practice. Published by Elsevier Ltd., Amsterdam, Netherlands.

Vodopiji-Krstanoviae, I. and Btala-Vukanoviae, M. (2012). EFL students' perspectives on English: the (widening) gap between ideals and practices. Revista Brasileira de Linguística Aplicada, v. 12, n. 2, pp. 285-309. doi: 10.1016/j.sbspro.2010.07.005

VyGotsky, L.S. (I962). Thought and Language. Cambridge MA: MIT Press.

Vygotsky, L.S. (1978). Mind in Society. Cambridge, MA: Harvard University Press.

WendEL, J.N. (2005). Notes on the ecology of language. Bunkyo Gakuin University Academic Journal 5, pp. 51-76.

Wenger, E. (1998). Communities of Practice: Learning, Meaning and Identity. Cambridge and New York: Cambridge University Press.

Williams, Cen ( I994). Arfarniad o Ddulliau Dysgu ac Addysgu yng Nghyd-destun Addysg Uwchradd Ddwyieithog. Unpublished PhD thesis. Bangor: University of Wales.

Williams, Cen (I996). Secondary education: Teaching in the bilingual situation. In C. Williams, G. Lewis, G. and C. Baker (eds.) The Language Policy: Taking Stock. Llangefni (Wales): CAI. Wittgenstein, L. (1980) Culture and Value. Chicago IL: University of Chicago Press.

Wright, S. (2004). Language Policy and Language Planning. From Nationalism to Globalization. Palgrave. Macmillan.

YANo, Y. (2006). Cross-cultural Communication and English as an International Language, Intercultural Communication Studies XV-3. Waseda University, Japan. 